\title{
Samuel Plimsoll and the 1880 Carriage of Grain Legislation
}

\section{William Glover}

Porte-parole et fauteur de troubles, Samuel Plimsoll prônait l'amélioration de la sécurité en mer, surtout au moyen de lignes de charges sur les flancs des navires. Il a également fait campagne pour une meilleure sécurité des cargaisons de grains dangereuses. Mais il était aussi impétueux, affichait une ignorance au niveau des causes $q u$ 'il défendait et, souvent, accordait peu d'attention aux faits. Dans quelle mesure a-t-il réussi à obtenir de véritables changements législatifs? L'auteur compare les arguments de Plimsoll relatifs aux cargaisons de grains à sa campagne précédente sur les lignes de charges qui, aux dires de l'auteur, a été menée à bien sans son intervention par d'autres qui comprenaient les problèmes. La résolution de la question des cargaisons de grains s'est-elle avérée différente?

"In September 1880 an Act was finally passed to provide for safe carriage of grain cargoes. Suddenly legislation that Plimsoll had hoped to pass was in place." Is this correct? It resulted from an agitation that Samuel Plimsoll, Liberal MP for Derby and a well known advocate for improving safety at sea, had started about grain cargoes. The legislation was based on a select committee report recommending that measures "already adopted voluntarily by the majority of shipowners, should be made compulsory by legislative enactment." ${ }^{2}$ Is it credible that he wanted no more than what responsible shipowners were already doing? Can the influences

\footnotetext{
1 Nicolette Jones, The Plimsoll Sensation: The Great Campaign to Saves Lives at Sea (London: Abacus [paperback], 2007) 256.

2 Great Britain, House of Commons, Report of the Select Committee on Merchant Shipping 23 July 1880 (Select Committee), iii.
}

The Northern Mariner / Le marin du nord, XXX, No. 4 (Winter 2020), 419-448 
that shaped the legislation be identified and traced to Plimsoll or to other sources? As the grain cargoes agitation followed a similar campaign for a load line, what does a comparison of the two campaigns suggest? ${ }^{3}$

Plimsoll was a coal merchant who had broken monopoly barriers to move his product by train rather than sea. ${ }^{4}$ After his election to Parliament in 1868 he began searching for a "cause" that he could make his own. In February 1870 Plimsoll met James Hall, the managing partner with Messrs Palmer Hall \& Co., a Newcastle merchant's firm. ${ }^{5}$ Hall was an advocate against the overloading of ships and spoke about it at a London meeting of the Associated Chambers of Commerce where Plimsoll was present. He had found his cause to champion and by July he was speaking to it in the House of Commons. ${ }^{6}$ He followed others.

The first MP to champion shipping reform had been James Silk Buckingham, elected from Sheffield after the great Reform Bill. He had served in both the Royal Navy and the merchant navy, and had held command in the latter. In 1836 he persuaded the House to appoint a select committee to investigate the causes of loss at sea. The report identified a number of factors including: poor design, still a concern in 1880 although for different specific issues; the tonnage laws, which were to be the subject of a royal commission in 1881; excessive insurance, such that even if a ship was lost, the owners made a profit, finally subject of legislation in 1906, and the incompetence of ships' masters and mates. Recognizing that the government would not act, Buckingham brought in a private members bill in 1837 proposing that ships' officers should be examined. The president of the Board of Trade, Charles Poulett Thomson (later the Baron Sydenham and appointed the first governor general of the united Province of Canada), spoke forcefully against giving the bill a second reading. ${ }^{7} \mathrm{He}$ described the examinations as "an unjust interference with the rights of the shipping interest." 8 That the requirement that a ship owner could only appoint to his ships officers who had certificates was seen

\footnotetext{
3 It is a pleasure to thank to the referees for their comments. I hope they will recognize the benefits. 4 Jones, 34-6.

5 Captain George Palmer (1789 - 1866) was a Greenland whaling captain who retired from the sea in 1833 after two very successful voyages, and became a Newcastle merchant, dealing amongst other things in timber. (Bernard Stonehouse and Caroline Gunn, "The Arctic Whaling Logs of Captain George Palmer, 1820-33," The Journal of the Hakluyt Society April 2013.) Messrs Palmer Hall \& Co. had sawmills. (B. Plummer, Jr., Newcastle-Upon-Tyne: Its Trade and Manufactures, NewcastleUpon-Tyne: Reed Printing, 1874, 63). Captain Palmer was the father of Charles Mark Palmer, MP, who established Palmer Shipbuilding at Jarrow on the south bank of the Tyne.

6 Captain Neville Upham, The Load Line - A Hallmark of Safety (London: National Maritime Museum, Maritime Monographs and Reports No 33 - 1978), 9-10; Jones, 68.

7 When a bill is read the first time a majority vote allows it to come to the floor. A second reading debate, which in this instance was defeated, would advance a bill to committee for clause by clause review. The bill as it may have been amended is then voted on in the committee and if accepted returns to the House for a third reading.

8 Jane Hanna Wilde, "British Legislation Concerning Shipping and Safety at Sea, 1803 - 1894" (PhD thesis, University of Wisconsin, 1955), 139. My thanks to Prof. Roger Sarty for providing me a pdf copy.
} 
as an interference is an index of the force of conviction of the laissez faire ideology of the day with respect to government regulation. This was certainly still prevalent in 1880 amongst the Board of Trade senior officials and an obstacle Plimsoll had to surmount.

Almost as quickly as he found his cause, Plimsoll began to establish a reputation for inaccuracy if not plain disregard of fact. Safety at sea burst on the national scene in January 1873 following the publication of his Our Seamen. The book showed a cavalier disregard for facts when they got in the way and Plimsoll generally seems to have had a naively simplistic understanding of the problems he championed. In short, he would appear to have been an embryonic prototype of the populist politician of the twenty-first century.

For an uncritical audience Our Seamen hit a responsive chord. He blamed rotten ships, corrupt owners and unsafe or even excessive loading for the casualties at sea. John Glover, ${ }^{9}$ senior partner of Glover Brothers, a London firm of shipping agents and shipowners, a prominent member of the London shipping community and an active fellow of the London Statistical Society, ${ }^{10}$ answered Plimsoll's book with an eviscerating exposure of the argument. He responded to Plimsoll's appeal to the reader for help by saying "the best help I could give to Mr. Plimsoll's cause was to add to his facts and half facts, further facts which are essential to sound judgement on the subject either by the public or by Parliament." He stated his object as "mainly to direct the excitement Mr. Plimsoll has made to steps, which while discriminating between bad shipowners and good ones, would be effective against the former without being vexatious to the latter." Throughout the work Glover used Plimsoll's own words and evidence to refute his charges. For example, to the statement that "a great number of ships are sent regularly to sea in such rotten and otherwise ill-found state that they can only reach their destination through fair weather," he quoted Plimsoll, "a noticeable feature of this list [of losses and

9 My great grandfather, the Rev. Dr Richard Glover (6 Jan 1837 - 26 Mar 1919), was the youngest of eight sons. His brothers included John, later Sir John Glover (6 Sep 1829 - 24 Mar 1920), chairman of Lloyd's Register of Shipping 1899 - 1907, and Septimus Glover (21 Feb 1834 - 2 Aug 1908), chairman of the Baltic Exchange 1898 - 1900.

10 John Glover was elected as a committee member of Lloyd's Register of Shipping in 1872 and served on the committee until 1911. He was an underwriting member of Lloyd's Insurance from 1874 to 1900 . He was chairman of the London General Shipowners' Society in 1876-7, 1887-8 and 1892-3. He became president of the Chamber of Shipping in February 1880. In 1881 he was a commissioner on the Royal Commission on Tonnage. An active member the London Statistical Society, their obituary notice of him said: "Since 1860 Sir John had been a Fellow of the Society, and served at intervals in the Council from 1869 to 1909, when he finally retired from that position. He was a Vice-President in 1885, 1887 and in 1903.... Sir John Glover contributed to the Society a series of no less than five Papers on Tonnage Statistics at intervals of ten years, thus extending over fifty years in all, the last one being read to the Society in 1902. This must indeed be a record of successive work which was quite inadequately recognized by the award in 1893 of the Guy Medal in silver [for using a set of statistics compiled by someone else] on the completion of his fourth decennial review of shipping." (“Sir John Glover," Journal of the Royal Statistical Society 83:3 (May, 1920), 521). I am indebted to Janet Foster, archivist of the Royal Statistical Society, for this. 
casualties] is that ships COMPARATIVELY NEW ARE LOST in greater proportion than those which are old." Glover added, "he does not prove the rotten theory which is assumed to be one of the two chief causes of wreck." He went on to demonstrate that the greatest loss of life was in the Irish Sea, with only 7 per cent of the wrecks while the most numerous wrecks, 56 per cent, were on the East Coast, where "old rotten colliers are most numerous." On the loss of life, contrary to Plimsoll but again using his statistics, Glover noted, "the recent changes have been in the right direction; there were 200 fewer lives lost in 1871 than in 1861, and the recent facts mark a steadily progressive improvement." On the causes of wrecks, Plimsoll's figures showed that the greatest proportion were from bad weather, approximately one third of that figure caused by carelessness and inattention of the crew, and just over half the latter figure were wrecks caused by defects of the ship or equipment. ${ }^{11}$ Given the steady increase in shipping, Glover stressed that the actual numbers must be looked at as a percentage of the whole trade. ${ }^{12}$

As is so frequently true with populist causes, facts mattered little. Attempting to quell the public unrest about shipping Plimsoll had caused, in March 1873 Prime Minister Gladstone's government announced the Royal Commission on Unseaworthy Ships, chaired by the Duke of Somerset. They were required to investigate a number of topics related to unseaworthiness including overloading and load lines. ${ }^{13}$

Plimsoll appeared as a witness on 9 May 1873 and again on 10 June. The preliminary report of 22 September was not complimentary. Three times the commissioners felt it necessary to comment on his evidence.

Mr. Plimsoll stated that there had been few inquiries [into losses of ships] until the pressure of public opinion had constrained the Board of Trade to undertake these duties In support of this allegation he said that there were only three inquiries in the year 1869 .

A reference to the returns proves that in that year there were 37 inquiries. We might, if necessary, point out many other inaccuracies in his statements, but he has the merit of having called attention to the loss of life which occurs in the mercantile marine from the culpable neglect of shipowners, as well as from other preventible causes. Some allowance may therefore be made for mis-statements and exaggerations which we were occasionally obliged to notice.

And, "in some cases the courts appear to have decided with imperfect knowledge of the facts, but there is no ground for the imputation made by Mr. Plimsoll,

\footnotetext{
11 John Glover, The Plimsoll Sensation. A Reply (London: Effingham Wilson, Royal Exchange, 1873), 4-8.

12 Ibid., 10-11.

13 Great Britain, Preliminary Report of the Royal Commission on Unseaworthy Ships (London: HMSO, 1873), iii \& iv, 29.
} 
that the Board of Trade desired to screen the shipowners." 14 Then finally, "the witnesses suggested to the Commission by Mr. Plimsoll did not much assist our investigations, and we lost valuable time in trying to elicit facts from the casual observations and unrecorded recollections relating to former events. We obtained, however, more trustworthy evidence from other sources." 15 Arthur Cohen, also a Liberal MP who later became a member of the select committee that examined the grain cargoes bill, signed this as a commissioner. The report also found, "in accordance with the evidence which we have obtained, we cannot recommend any enactment for establishing a fixed load-line founded on the proportion of freeboard to the depth of hold of the vessel. Whether any other scale of measurement could be adopted as a guide for the safe loading of merchant ships is a matter of such importance, that we must reserve our opinion until we shall have had more time fully to examine the question." ${ }^{16}$ The final report of July 1874 made no load line recommendation.

An election early in 1874 led to a change of government, and Benjamin Disraeli became prime minister at the head of a Conservative administration. He appointed Sir Charles Adderley as the president of the Board of Trade but without a cabinet seat. Plimsoll introduced a bill that would have required the Board of Trade to mark a firm fixed load line. Despite the identified complexities in the report on unseaworthy ships and significant technical disagreement among experts on how to proceed, at second reading in June 1874 Plimsoll's bill failed by only three votes. This forced Adderley to introduce a merchant shipping bill addressing at least some concerns for shipping reform. ${ }^{17}$ However it was not a high government priority and in July 1875 with the end of a session approaching, it was withdrawn. This prompted a furious outburst from Plimsoll who shook his fist in Disraeli's face. The House of Commons was aghast at this unparliamentary behaviour but the public supported Plimsoll. Again, something had to be done. As a temporary measure, the Unseaworthy Ships Act which gave the Board of Trade the power to detain ships thought to be unseaworthy, was introduced on 28 July. It was amended to include an earlier proposal from Charles Norwood, a Liberal MP and shipowner who had unsuccessfully sued Plimsoll over Our Seamen, that required shipowners to mark a load line on the ship's side for each voyage beyond which the owner did not intend to load the vessel. The bill received royal assent on 13 August.

In February 1876 Adderley introduced legislation to make the temporary measure permanent. He noted that all the measures of the temporary bill and which with one exception had been in his bill that was dropped, were now in the legislation he was proposing. ${ }^{18}$ When it finally received third reading on 28 May it

\footnotetext{
14 Ibid., xiii.

15 Ibid., xvii.

16 Ibid., v.

17 Geoffrey Alderman, "Samuel Plimsoll and the Shipping Interest," Maritime History 1:1 (April 1971), $80-1$.

18 Great Britain, House of Commons Debates,” https://api.parliament.uk/historic-hansard/commons/
} 
had been debated in the House or by the Committee of the Whole on twelve sitting days. On at least one occasion the debate had lasted eight hours. The owners' load line, part of the 1875 temporary measure, was made permanent in the 1876 bill with Plimsoll's apparent support. ${ }^{19}$ Although he later recanted his support, he nonetheless felt able to tell his constituents in September 1878, "my special work is done." 20

Plimsoll's assessment of his work would seem to anticipate a "mission accomplished" type of remark. The owner's load line was widely derided as being a farce and a delusion. Thomas Farrer, who thirty years earlier had been the first head of the Board of Trade's new Marine Department and was now the permanent secretary to the Board of Trade, giving opinion evidence before the 1880 select committee said he never liked it and thought it should be discontinued. ${ }^{21}$ The question of how to mark a load line was not resolved until 1885. In late 1883, Joseph Chamberlain, an early stalwart Plimsoll supporter ${ }^{22}$ and the president of the Board of Trade, had appointed a committee of experts to investigate the load line problem chaired by Sir Edward Reed, MP, who had been the chief constructor of the navy. In August 1885 they submitted a unanimous report providing tables for the marking of load lines on ships of various types. ${ }^{23}$ It was finally incorporated in legislation in 1890 .

What had Plimsoll achieved? As the 1873 royal commission had observed, Plimsoll deserved credit for calling attention to a serious problem. When it might otherwise have been addressed is a matter of conjecture. But the heavy lifting to resolve the problem was done by others and was not completed for seven years after he declared his work done. A contemporary assessment saw both his warts and achievements: "although he spoke and acted with all the vigour of conviction and with all the tireless energy of an enthusiast, he really knew in his own person very little of the subject to which his public life was devoted, and in which, in spite of the difficulties thrown in his way by want of experience, he did a great deal of very valuable service." ${ }^{24}$ With the advantage of historical hindsight a biographer of Lord Shaftesbury, a great Plimsoll supporter, wrote "earnest, impetuous, and with little regard either for truth or accuracy, Plimsoll was a man who, left to himself, could be guaranteed to ruin the best of causes." 25

\footnotetext{
Merchant Shipping Bill, Leave, First Reading, 10 February 1876, col 164. (Future notes will be HC Deb, date, and column number.)

19 Alderman, 87.

20 Jones, 241, 327.

21 Select Committee, questions (q) 6366-68.

22 Chamberlain, as lord mayor of Birmingham, had chaired an 1875 rally at Birmingham in support of Plimsoll and his campaign for a load line. Jones, 180.

${ }_{23}$ Great Britain, Report of the Load Line Committee to the President of the Board of Trade (London: Eyre and Spottiswoode, 1885).

24 Plimosll obituary, Times (London), 4 June 1898, cited in Wilde thesis, 303.

25 Georgina Battiscombe, Shaftesbury: The Great Reformer, 1801 - 1885 (Boston: Houghton Mifflin Company, 1975), 310.
} 
The hazards of grain cargoes were another of Plimsoll's causes. "A combination of ignorance, inexperience and often no doubt negligence in pursuit of a speedy turn-around time gave rise to heavy casualties in the grain trade in the late $1860 \mathrm{~s}$ and early 1870s." 26 The problem was studied by Somerset's commission. However, they recommended no legislative action. "Grain cargoes are attended with danger to life, and require exceptional care. The rapid mode lately adopted for loading the grain ships adds to the danger. There are however well known precautions tending to diminish this danger, but the application of these will be best left to the responsibility of the shipowner and the practical knowledge of the captain." ${ }^{27}$ This laissez faire approach was in contrast to loading practices at Montreal and New York. The Canadian parliament had adopted legislation in 1873 that allowed for strict regulation of loading grain at Montreal. In New York since 1860 the underwriters had been issuing rules for the stowage of grain that had to be followed if the cargo was to be insured.

The temporary Unseaworthy Ships Act that required the owners' load line had also been amended to include grain cargoes. When the House had moved into the Committee of the Whole to consider the bill, Reed had opened the debate saying that "the overloading of merchant ships cannot be effectively restrained unless owners and captains are prohibited from loading their ships beyond a load-line limit of safety." He went on to say he "felt it was very desirable [the bill] should make provision for the regulation of deck cargoes and cargoes of grain." 28 When he came to move his amendment that a grain cargo could not be carried except in "bags, sacks, or barrels or throughly secured from shifting by boards, bulkheads or otherwise" the chancellor of the Exchequer responded, "the Committee would be acting hastily and unwisely, if they were to introduce into the present temporary measure a proviso of the kind proposed." However, as he listened to the debate he relented. He asked that Reed agree to delete a requirement that a ship carrying a bulk grain cargo be considered unseaworthy and that he agree to another proposed amendment that it only apply to cargoes of which more than one-third was grain. He did. ${ }^{29}$ The amendment was adopted.

The following year when the temporary measure was made permanent grain cargoes were debated again. E.T. Gourley followed Adderley in the first reading debate. A former councillor and mayor for Sunderland, he became the Liberal MP in 1868. On the grain question he noted, "it was proposed that the grain-loading clauses should be left as they were last year; but he adhered to his own opinion that the only way of dealing with the matter was to provide that one-fourth of the cargo

\footnotetext{
26 David M. Williams, "State Regulation of Merchant Shipping 1839 - 1914: The Bulk Carrying Trades," in Sarah Palmer and Glyndwr Williams, eds., Charted and Uncharted Waters: Proceedings of a Conference on the Study of British Maritime History (London: National Maritime Museum, [1981]), 63.

27 Cited in ibid., 64.

28 HC Deb 2 August 1875, c380.

29 Ibid., cc426, 427, 430.
} 
should be stowed in bags and loaded on the top of the bulk." ${ }^{30}$

The debate to read the permanent bill a second time was on 17 February 1876. The parliamentary secretary to the president of the Board of Trade clearly outlined the fundamental difference of approach between the government, and Plimsoll and his supporters. In the legislation the government "wished to impress upon shipowners the responsibility of the business in which they were engaged, and to require them to show that in all cases they had taken reasonable pains to secure seaworthiness in the ships they sent to sea." Lord Eslington, a Conservative MP and former member of the 1873 Royal Commission on Unseaworthy Ships, was even more direct. "It was very proper to rivet upon the shipowners the full responsibility of any action on their part which might endanger the safety of ships and the possible loss of valuable lives." ${ }^{31}$ Granted second reading, the bill went to the House sitting as the Committee of the Whole for clause by clause consideration.

To prevent unseaworthy ships going to sea, Plimsoll had wanted the government or perhaps Lloyds Register to provide a certificate of seaworthiness. Without it, a ship could not sail, but with it, as was pointed out, the owner or master was protected from any legal action. When it came to grain cargoes Plimsoll was even more prescriptive. He wanted to amend the clause, the same as in the temporary bill, to require "shifting boards not less than two and a half inches in thickness, running from the keelson or screw tunnel, as the case may be, longitudinally throughout the part of the ship so loaded, and up to the underside of the planking of the deck next above the top of such grain cargo, and also by having not less than one-fourth of such grain cargo in sacks or bags laid upon the surface of the remaining three-fourths of such cargo loaded in bulk." ${ }^{32}$ Adderley in reply said the amendment

would prevent any adaptations of grain ships to the various wants of the trade, and the use of longitudinal iron bulk-heads would be excluded if shifting boards were made universally compulsory. ... There were many different modes of securing grain cargoes from different countries. In some of the American ports, for example, it was usual to mix cotton with the grain; while, in other ports, the cargo was prevented from shifting by placing grain in sacks upon the top. Cunard's grain ships were fitted in layers, and other lines used bins. All these arrangements, however completely they effected the purpose, would be prohibited if the Amendment were agreed to. It was true that measures were taken in Canada to guard against the shifting of grain cargoes, but that was done not by rigid rules, but at the

30 HC Deb 10 February 1876, c179.

31 HC Deb 17 February 1876, cc451, 457. Lord Eslington was the courtesy title of the eldest son and heir of Earl of Ravensworth. He was therefore not a member of the House of Lords but rather an elected MP in the House of Commons. In 1880, two years after he had succeeded as the earl, he was elected president of the Institution of Naval Architects.

32 Ibid., 24 April 1876, c1580. 
discretion of the port officers. ${ }^{33}$

Norwood then observed "if, however, the Amendment were adopted, the owner by carrying out a specific plan in a perfunctory manner would escape all responsibility." After another MP noted that Plimsoll "had just told the Committee that the Canadian system of loading was the most complete" and asked if "its adoption might not be entirely prevented by the amendment," Plimsoll withdrew it. $^{34}$

Yet Plimsoll learned nothing from this exchange. When the Committee of the Whole had completed their examination and the bill had been reported to the House of Commons for third reading, he tried again. On 22 May he moved an amendment for grain ships coming out of the Straits of Gibralter or the Baltic that "the grain on the right or starboard side of the ship shall at the least be securely and entirely separated from that on the left or port side, and that not less than one-third of the grain cargo shall be in sacks, bags, or barrels." Adderley correctly observed that "the Amendment [was] much too minute, and that a better security for the purpose in view was given by the general penalty on insecure stowage. Besides the only officers boarding all ships arriving did not stay long enough to ascertain such minute particulars even if it were desirable to enact them." It was defeated on a voice vote. ${ }^{35}$

On grain cargoes Plimsoll ultimately had one albeit contradictory success. His amendment to extend responsibility from just the master to the managing owner was accepted by the government after he agreed to include the owner's agent. Yet as government supporters had frequently noted, he had repeatedly tried to shift responsibility off the owner. Eslington, in the debate about marking load lines, had been "astonished at the discrepancy which existed between the views expressed by [Plimsoll] and his line of action. He expressed distrust of the Department, and yet continually proposed to throw new duties upon it."36

With no further substantive debate, the bill was given third reading and passed on 26 May. After royal assent the grain cargoes clause became section 22 of the 1876 Merchant Shipping Act.

No cargo of which more than one-third consists of any kind of grain, corn, rice, paddy, pulse, seeds, nuts or nut kernels, hereinafter referred to as grain cargo, shall be carried on board any British ship, unless such grain cargo be contained in bags, sacks, or barrels, or secured from shifting by boards, bulkheads or otherwise. If the managing owner or master of any British ship, or any agent of such owner who is charged with the loading of the ship, or sending her to sea knowingly allows any grain cargo, or

33 Ibid., c1582.

34 Ibid., cc1584-5.

35 Ibid., 22 May 1876, c1072.

36 Ibid., 27 April 1876, cc1808-9. 
part of a grain cargo to be shipped therein contrary to the provisions of this section, he shall for every such offense, incur a penalty not exceeding $£ 300$ to be recovered upon summary conviction. ${ }^{37}$

And so things remained until 1880 .

On 2 January 1880 the Times quoted a letter from Plimsoll of 24 December saying he would seek reform of the carriage of grain cargoes. ${ }^{38}$ Six ships recently lost, "nearly all of which carried many brave men and fathers of families to a watery grave, compel me ... in a strenuous effort to reform such a dreadful practice as loading grain in bulk." He proposed speaking to his constituents about this on 2 February. Papers later given to a select committee provided details on three of them: the Heimdal, lost 2 November and the Tiara and Emblehope, both lost 29 November. The court for the Heimdal, 30 January, found that the captain had not properly secured the cargo. All of the Heimdal's crew of twenty-nine were able to leave the ship in boats, but two died before they could be picked up. Of the latter two, the courts of inquiry reports dated 14 February 1880 named want of stability because the centre of gravity was too high as the cause of loss, not bulk grain cargo shifting. No men were lost from either ship. ${ }^{39}$ As of 24 February, the inquires of the Joseph Pease and the Telford were still pending. Therefore when Plimsoll made his decision to agitate about grain cargoes he did not have the facts. His case would not be supported by the facts of at least half the ships he named.

On 24 January he met in London with members of the Trades Union Congress to discuss grain cargoes. ${ }^{40}$ Although sailors were not then organized in any way, the trades unions would obviously be sympathetic to causes of safety and had an organization with members who could be mobilized. Two weeks later he had prepared and introduced a bill amending the merchant shipping act to regulate the carriage of grain cargoes. It was given first reading and printed by order of the House of Commons on 6 February. The bill sought to prohibit any British ship whose cargo was more than one-third in grain, from carrying that grain unless it was in bags, sacks or barrels. He proposed deleting the provision that allowed the grain to be secured from shifting by boards, bulkheads or otherwise. It was placed on the order paper for second reading the following week.

In accordance with the House of Commons rules, if a member provided notice of an objection to an item on the order paper, therefore implying a longer debate, the matter could not be introduced if it was later than half past midnight. ${ }^{41}$ Both

\footnotetext{
37 Select Committee, q5599.

38 Cited in Wilde, $408 \mathrm{n} 8$. As the Times is not part of the British Newspaper Archive available on line, during this covid period I had been unable to confirm that report. Again Prof. Sarty was also able to get that reference for me.

39 Select Committee App 11, Heimdal 368; Tiara 386; Emblehope 392.

40 Jones, 327.

41 This is drawn from Sir Charles Russell's speech, HC Deb 17 February 1880 cc797-8. Plimsoll chose to forget that during the 1876 Committee of the Whole deliberations, he had voted to adjourn the committee after midnight "because he had sat there so many hours that he was tired." (HC Deb 3
} 
Sir Charles Russell, Bt, VC, (Westminster) and Denzil Onslow (Guildford) had objected because they believed the subject of such importance to merit a full debate. Plimsoll interpreted this as a procedural attempt to block his bill, and was incensed. He ordered placards in his name and dated 12 February to be printed and distributed in the constituencies of the two Conservative members. The language was inflammatory and at least some of the "facts" were fake, and subsequently contradicted in the House. It alleged a large number of lives were lost, and would be again the next winter. He claimed, "this change in the Law is strongly advocated by the Chamber of Commerce of Newcastle-on-Tyne; also by that of Gateshead." Plimsoll wrote, "I ask you to say, whether, if Sir Charles Russell has done this thing of his own motion, it is not inhuman? and, if he is merely the cat's paw of some who wish to oppose (but dare not openly for fear of their Constituents) it is not degrading!" Russell, supported by others, argued that this constituted a breach of Parliamentary privilege, in that Russell was merely following adopted rules of procedure. Before the debate was adjourned, Charles Mark Palmer, owner of Palmer's Shipbuilding and Iron Company Limited at Jarrow on the Tyne and the Liberal MP for North Durham pointed to specific errors in Plimsoll's placard. The owners of the Tiara and Trident (two of the ships Plimsoll named) telegraphed Palmer that one of the ships had been lost by collision off the Goodwin Sands and the other had not been carrying grain. No lives were lost in either case. He concluded by noting that he was the president of the Newcastle and Gateshead Chamber of Commerce. Contrary to Plimsoll's allegation of strong advocacy for his bill by that body, "there was a very divided opinion in the Chamber in regard to the Bill, and also among the shipowners of the North generally." 42 On 20 February following further lengthy debate on the point of privilege his action was found indeed to have been a breach, but because he had apologized, and it had been accepted by both injured parties, he escaped the contemplated censure he had previously suffered when he shook his fist in Prime Minister Disraeli's face. ${ }^{43}$

On 24 February Viscount Sandon, ${ }^{44}$ the president of the Board of Trade, moved that a select committee ${ }^{45}$ be appointed to inquire about the recent loss of ships. Was it because of the cargo, construction problems or something else? Did law need to be changed $?^{46}$ It quickly became apparent that despite the veneer of all

\footnotetext{
Apr $1876 \mathrm{c} 1161)$.

${ }_{42}$ HC Deb 17 February 1880, c809.

43 HC Deb 20 February 1880, cc1108-58.

44 As the son and heir of the Earl of Harrowby, this was a courtesy title.

45 Parliamentary process can be convoluted. By motion, a committee can be established to investigate a matter. Once established, that committee could include as part of that investigation a bill, related to the specific matter, that has not yet been read a second time. That is what Sandon was doing. Otherwise, a bill could only be referred to the Committee of the Whole for further study after it has been read a second time. The committee's report on the bill would then be considered by the House at third reading. This distinction was obviously not understood by all MPs, eg Onslow, HC Deb 31 May 1880, c877.
}

46 HC Deb 24 February 1880, c1352. 
being in favour of saving lives at sea, this would be controversial. After discussing the merits of a select committee versus a royal commission, Sandon laid out the problem: "with the evidence he had before him, no Government or responsible Department would venture to support [Plimsoll's bill] without inquiry." He began his case with remarks made by Glover on becoming the chairman of the UK Chamber of Shipping.

I should point out that, so far from putting all wheat and maize into bags lessening losses in the American trade, it is certain the main cause of such losses would be aggravated thereby. It is well known that want of stability, rather than cargo shifting, has led to many of the recent disasters. So much weight of cargo is above the centre of gravity that the ships, in nautical phrase, 'turn turtle.' Grain in bulk occupies less space than grain in bags; consequently, with the same number of tons of weight on board, the vessel entirely laden with bags would have more weight above her centre than if she had grain in bulk below. ${ }^{47}$

This specific question would be hotly debated.

Sandon then challenged Plimsoll's factual accuracy on which he based the need for his bill. Plimsoll had alleged in his 12 February placard that sixteen ships which he named had been lost over the past year. Plimsoll had written "nearly all these ships were laden with grain only; one or two had besides grain a little general cargo" and "it is universally admitted that loading ships with grain in bulk is the principal cause of these losses, that to put it in bags or sacks would ensure safety." ${ }^{48}$ Sandon found that four (Bernina, Homer, Zanzibar and Surbiton), were not grain ships. Another four he was able to dismiss as having been lost for reasons unrelated to shifting cargo. Of the balance, human error was at fault in two, in two more courts of inquiry questioned the basic stability of the vessels and in two others inquiries were still pending. Of sixteen ships, that left two that might have been victims of shifting grain cargoes. But Sandon noted that in the last three months, twelve ships had been lost. Seven carried grain and five coal. This suggested that construction of the ships may have been at fault. ${ }^{49}$

In concluding the lengthy debate to establish the select committee, Sandon said, "nothing would induce the Government to assent to the Second Reading of his Bill until investigation had convinced them that it really was required for the preservation of human life, and that it would not have the effect of destroying the great shipping interests upon which this country so much depended." 50

Two days later, using the procedural ploy of moving adjournment, Plimsoll contradicted Sandon's assessment of the four named ships as having mixed or

\footnotetext{
47 Ibid., c1354.

48 HC Deb 17 February 1880, c798.

49 HC Deb 24 February 1880, c1358.

50 Ibid., cc1381-2.
} 
general cargo. "He had obtained copious extracts from the manifests of the ships lodged at the ports of shipping." Of the Homer, a Glover Brothers ship, he said the general cargo in fact was " 1,509 barrels of apples, 35,990 lb. of bacon, 5,000 lb. of butter, 1,238 lb. of cheese, and 286,500 lb. of lard, making in all 299 tons; while she had onboard 43,642 bushels of wheat, weighing 1,091 tons." ${ }^{51}$ Correcting Plimsoll, on 1 March Glover wrote to Thomas Gray, the assistant secretary in charge of the Marine Department: "the weight of the general cargo on board we believe to have been 921 tons, after the most careful computation." He also noted, "part of the grain was in sacks, but the exact quantity we do not know." 52

On 5 March when the select committee was nominated, Plimsoll raised new concerns. First, in support of his contention of the need to regulate grain cargoes, he noted the higher insurance premiums for transatlantic cargoes than for cargoes coming from other, even more distant ports. He observed that six proposed members were shipowners, implying that they would be self interested, and deplored the absence of any shipbuilders. He suggested that Edward Reed (he would be knighted in August) or Charles Palmer should be appointed "because in the course of the discussion which had taken place a great deal of nonsense had been talked with respect to the raising of the centre of gravity, which would have been exposed in a moment by the hon. Members to whom he had referred." ${ }^{53}$ That suggestion was ironic; it was Plimsoll himself, relying on the word of William Dickinson a shipowner from Newcastle, who spoke the nonsense. On the other hand, Reed was responsible for considerable advances in understanding stability, "even though many, including some well-qualified naval architects, failed to understand the implications of this new work." 54

The committee met on 9 March and quickly concluded "that in the present circumstances of the existing Parliament, and the unavoidable absence of Members of the Committee, and the short time which intervenes before the actual Dissolution, it is not expedient to proceed" and they recommended a new committee be established by the next Parliament. ${ }^{55}$ Dissolution was granted at the end of the month, and the election held over the period 31 March to 27 April. With it came a change of government. Disraeli's Conservatives were defeated, and W.E. Gladstone became prime minister again.

In the new government Sir William Harcourt who was first elected from

\footnotetext{
HC Deb, 26 February 1880, cc1446-1447.

52 Select Committee, Appendix 13, 431.

53 HC Deb 05 March 1880, c533.

54 David K. Brown, RCNC, Warrior to Dreadnought: Warship Development 1860 - 1905 (London: Chatham Publishing, 1997), Appendix 4, 207. See also his entry for Reed in the Dictionary of National Biography: "The design work [for HMS Captain] was carried out by Lairds but the design revolution described above [by Reed] had not reached Birkenhead and the company greatly underestimated the weight of such a ship while its estimate of the height of the centre of gravity was an inaccurate guess."

55 Great Britain, House of Commons, Report of the Select Committee on Merchant Ships Laden in Bulk, 9 March 1880, iii.
} 
Oxford in 1868 and was a former solicitor general, was appointed the home secretary. Unfortunately, Harcourt lost the by-election made necessary by his cabinet position, and another constituency had to be found. He was "rescued by Plimsoll." "Plimsoll called his supporters together at Derby and, recalling the help received in the past for his work for the seamen from Harcourt, and pointing out that as Home Secretary Sir William would be able to do much more for the cause he had at heart than he could do as a private member, induced them to accept his resignation." ${ }^{56}$ Given his behaviour in the House as recently as February that was similar to his earlier outrage against Disraeli, he was doubtless correct. Plimsoll stepped aside on 18 May and Harcourt won his by-election one week later.

Joseph Chamberlain was appointed president of the Board of Trade. "One of [his] first acts in office was to write to Plimsoll ... asking ... him to visit for [a] private exploratory discussion." ${ }^{, 57}$ Less than two weeks after that meeting, on 21 May, Chamberlain moved in the House of Commons "that a Select Committee be appointed, to make inquiry concerning the losses of British Ships, missing and foundered, since the passing of The Merchant Shipping Act, 1873; to ascertain the causes of such losses; to inquire into the operation of legislation as affecting them; and to report whether any change in the Law affecting Merchant Shipping or Maritime Insurance is required to prevent such losses." 58 As Viscount Sandon noted, this mandate was much broader than he had proposed for the March select committee. Excessive insurance as a factor of ship loss was a favourite topic for Plimsoll. ${ }^{59}$ After that brief intervention, the motion was approved.

Later that same day George Anderson, a Liberal MP for Glasgow and a sponsor of Plimsoll's bill in February, introduced a new bill for grain cargoes. Two sponsors of the first bill were joined by Charles Wilson, David MacIver ${ }^{60}$ and Gourley. Wilson's family owned a shipping firm and he was the Liberal MP for Hull. David MacIver was the Conservative MP for the Liverpool area constituency of Birkenhead. He was a partner in his father's firm D. and C. Mac Iver which in turn were partners with Cunard and had managed the line since $1840 .{ }^{61}$

Anderson's bill repeated Plimsoll's requirement that grain cargoes that were more than one-third of the total cargo could only be carried in bags, sacks or barrels. But, if the shipping port had a system of inspection and regulation that had

\footnotetext{
56 A.G. Gardiner, The Life of Sir William Harcourt (London: Constable \& Co., 1923), 1:365.

57 Peter T. Marsh, Joseph Chamberlain: Entrepreneur in Politics (New Haven and London: Yale University Press, 1994), 144; Jones, 327.

58 HC Deb 21 May 1880, cc286-7.

59 As long as an owner could insure his ship for more that its worth, as well as insure against lost profits in the event of loss, plus wages that might not be paid, an owner could actually profit if his ship sank. Hence the incentive to keep the ship in good repair and well found was, for at least some owners, not strong.

60 This is the spelling used in the report of the select committee. In Hansard it is spelled Mac Iver.

${ }^{61}$ Stephen Fox, Transatlantic: Samuel Cunard, Isambard Brunel, and the Great Atlantic Steamships (New York: Perennial, 2004), 106. As Mac Iver is used by Fox, so it is used here for the family and firm.
} 
been approved by the Board of Trade, grain cargoes from that port were exempted. Likewise, if the ship was so fitted for carrying bulk grain cargoes in a manner certified by the Board, that ship was exempted. Penalties for non-compliance were specified. On arrival at a British port the master had to notify Customs. Unloading could only start after the inspection of the cargo, which was to be within twentyfour hours. This was similar to an amendment Plimsoll had proposed in 1876 but was defeated. ${ }^{62}$ Any ship carrying a grain cargo regardless of nationality, that was not loaded in an acceptable manner could be charged double harbour dues. And finally, the act was for one year only. ${ }^{63}$

On 31 May Anderson moved that the grain cargoes bill be read a second time on the understanding that it would be referred for study to the select committee (that had been approved but not yet nominated). He said nothing further in its support. Comments of the other supporters are interesting for their contradictory positions. A Conservative sponsor was afraid that the bill might get lost in the committee, and never return. It was, he thought, a "very simple measure, and might, ... almost be passed by the House without referring it, inasmuch as it simply filled a blank in the Merchant Shipping Act which was passed by the last Parliament." 64 On the other hand, MacIver (also a Conservative sponsor), thought "several of the clauses would require considerable modification." ${ }_{65}$ Meanwhile Wilson noted he had presented a petition from the Chamber of Commerce in Hull who were "against the bill in its present shape." They were of the view that the bill should deal "only with the American trade in the winter months." He suggested that Anderson, in charge of the bill, "had departed from the original intention, and had extended it so as to include the English trade, and that had created a considerable amount of opposition to the measure." ${ }^{66}$ Gourley merely expressed the view that the grain trade should be examined quickly by the committee, while insurance would take a long time, and by implication it could wait. ${ }^{67}$ It was then agreed to refer the bill to a select committee.

The membership of the committee was resolved the next day. The debate, almost twice as long as the previous day, was not about the substance of the bill but process about the composition of the committee. For the first time the House had Irish MPs as distinct from MPs, either Liberal or Conservative, who happened to represent Irish constituencies. By what formula and at the expense of which party would there be Irish representation on the committee? The government prevailed. With twenty-seven members, fourteen were Liberal, eleven Conservative, and two Irish. Of the total, six were shipowners: two Conservative including MacIver, four

\footnotetext{
62 HC Deb. 22 May 1876, c1075.

63 Bill 168, Merchant Shipping (Grain Cargoes), 2 May 1880, House of Commons, Parliamentary Papers.

64 HC Deb 31 May 1880, c878.

65 Ibid., c879.

66 Ibid., c881.

67 Ibid.
} 
Liberal including Wilson and Gourley. Plimsoll had identified Gourley as a bad ship owner in his 1873 book. ${ }^{68}$ During the committee deliberations Gourley would have to weigh the quality of Plimsoll's evidence against that of two witnesses from the Sunderland shipping community who were probably well known to him. Reed and Palmer with extensive shipbuilding experience were both on the committee. Onslow who had been targeted by Plimsoll's placard campaign was one of the Conservatives. John Talbot, who had been Sandon's parliamentary secretary when Plimsoll launched his attack, was also a member.

Not surprisingly, Harcourt was also appointed to the committee. In the previous parliament he had spoken on shipping issues in support of Plimsoll. In the wake of the election, "his succession to Plimsoll at Derby had imposed [grain cargoes] on him as a personal trust." ${ }^{69} \mathrm{He}$ executed it with a vengeance. He was remarkably hostile to any witness he thought unfriendly towards Plimsoll. ${ }^{70}$ His questioning seemed to take the form of a cross examination in court, trying to trip them up by having them agree to things they had not said. Farrer was the most pointed in his response. In reply to a question from Wilson, he said, "I intended most distinctly to repudiate what the Home Secretary, in his forensic way, attempted to put in my mouth."71 Glover was obviously another anti-Plimsoll target. In addition to subjecting him to a hard cross examination, he tried to discredit him when questioning another witness, ${ }^{72}$

The committee first met on 7 June. Chamberlain was elected as chair, and the committee agreed to look first at just the Grain cargoes bill that had been referred to it. One might have thought that with two cabinet ministers both keen supporters of Plimsoll on the committee, a bill referred to them that was sponsored by another supporter and presented in succession to a Plimsoll initiative, would have had clear sailing. It was rejected. At the second meeting on 10 June they began hearing witnesses. The first was Farrer, who confined himself to submitting various returns that had been prepared by the Board of Trade with respect to ship losses. Printed as appendices to the committee report, their detail frequently challenged Plimsoll's statements. Appendix 10 was an "Analysis of Reports of Inquiries into Foundered or Missing Ships, 1879,1880." Of the fifty-one ships lost only thirteen had carried grain, against sixteen with coal cargoes and five with iron. Of the thirteen grain ships, in three instances cargo shifted because of "want of precautions" or what today would be human error. In seven ships the loss was not caused by shifting grain, even when loaded in bulk. In two of these, "want of stability" and "centre of gravity too high" were specifically identified. Of the sixteen ships carrying coal that were lost, in six cases instability was identified and in three of these the courts

\footnotetext{
68 Jones, 95.

69 Gardiner, 1: 375.

70 Glover, Laws, and Martell. He did not question Leyland, although present, and he was absent when Dunlop testified.

71 Select Committee, q6185.

72 Ibid., qq4164-70.
} 
found that stability calculations had never been made. (During his final appearance before the committee Farrer was able to submit recently found evidence, a bottle with a message had washed ashore, that confirmed the Zanzibar had capsized because of a stability problem. ${ }^{73}$ ) A further complication was that of the grain ships, two had the cargo in bags that shifted and three were loaded in bulk and it did not shift. So began a steady erosion of the reliability of statements by Plimsoll and his supporters, Harcourt's cross examinations notwithstanding.

Plimsoll was the second witness. He began his testimony by submitting a number of statistical returns with which he hoped to demonstrate loss of life at sea, that justified legislative action. Unfortunately they were refuted by Farrer's submissions. Plimsoll however emphatically believed that the principal cause of loss was bulk loading of grain because it shifted, even though he also acknowledged that bulk grain could be carried safely in the manner as loaded at Montreal since $1873 .{ }^{74}$ (The Canadian plan, as it was termed, was subject of much discussion.) On the problem of the centre of gravity, Plimsoll was dismissive: "All that about the centre of gravity is very great rot, and is only talked by either rogues or fools." He later repeated that sentiment when he called Sandon's comments about the centre of gravity being raised, "nonsense." 75 Overall his evidence was characterized by the sort exaggeration and false statements he made before the 1873 royal commission and in the House of Commons. He could also lose his temper. Like his December decision to try to stop grain cargoes in bulk, he was happy to make statements not based on fact. When asked by Wilson, "You try and give statements without proof?" he replied, "It would not be admissible in a court of law, but I do not admit that. I read the extract from a newspaper and let it go for what it is worth." ${ }^{\prime 76}$ What was not acceptable in a court of law he thought was acceptable in Parliament making law.

He shared an account in the Times of a December meeting of a shipmasters' association of the Tyne that adopted a resolution asking that the Board of Trade compel the carriage of grain in bags. ${ }^{77}$ While Plimsoll thought it supported his argument, it highlighted the problem of hearsay evidence. Perhaps in an attempt to support Plimsoll's argument, Chamberlain “ordered" Captain James Henderson to attend. ${ }^{78} \mathrm{He}$ was a master mariner from Sunderland and may therefore have been known at least to Gourley, if not other committee members. He had commanded sail for twenty-four years, had some time in steam and had experience of the grain trade "from all parts." 79 He became the secretary of the British Ship Masters' and Officers' Protection Society in 1874. He described the meeting which led to the

\footnotetext{
Ibid., q6096.

Ibid., qq115, 127, 201, 401.

Ibid., qq309, 552.

Ibid., qq250, 355.

Ibid., q118.

Ibid., q1706.

Ibid., qq1466-1481.
} 
Times report. At a meeting that December in North Shields "one of our members, a gentleman who has crossed the Atlantic Ocean a number of times in command of steam ships, brought a motion forward to the effect that the grain cargoes ought to be carried in bags, inasmuch as carrying grain in bulk was a fruitful source and cause of the loss of vessels. ... it was carried almost unanimously." ${ }^{80}$ At a meeting in February following Plimsoll's introduction of his bill, a motion to petition Parliament to support Plimsoll's bill was combined with a clause asking for an inquiry into the losses. While the support for the bag requirement was divided, agreement on the need for an inquiry was complete, and therefore the motion was adopted. But a requirement to bag grain cargoes was clearly a contentious issue amongst ships' masters. ${ }^{81}$

Plimsoll referred to a paper that Benjamin Martell, the chief surveyor of Lloyd's Register, read to the INA on 17 March $1880 .{ }^{82}$ (It was distributed to the committee. Reed, who had been instrumental in the INA's establishment and was a vice president, described the paper as "an extremely valuable one" when Martell later appeared before the committee ${ }^{83}$ ) Of it, Plimsoll said, "in this paper there are some very valuable figures, which are worth the attention of the Committee. It is the return of cargo steamers which were lost in the winter months alone." ${ }^{" 84}$ In his remarks, Plimsoll focussed on the hard numbers of losses in Martell's statistics rather than on the analysis. He missed, ignored or did not understand what Martell said:

In fact, the figures themselves in the Table of Losses show that there were as many coal-laden steamers as grain-laden steamers lost during the months of the past winter; and although it is possible for coal to shift similarly to grain, it is not a cargo which is prone to shift, or which would be considered dangerous in a fairly-designed vessel. In view of these facts there is nothing to show that the inherent deficiency of stability of the vessels, loaded as they were, might not have been as active an agent, if not a more active agent, in creating the disasters we deplore, as the shifting of the cargo. ${ }^{85}$

In total, Martell identified ten important causes of loss. ${ }^{86}$

Martell quickly dismissed his first, various problems of construction. Of the second, deterioration, causing local defects and unseaworthiness, he noted the consequences of galvanic action. That emphasized the need for regular inspections.

80 Ibid., q1490.

81 Ibid., qq1491-1500.

82 Benjamin Martell, "On Causes of Unseaworthiness in Merchant Steamers," Transactions of the Institution of Naval Architects 21 (London: Institution of Naval Architects, 1880), 1-57.

83 Select Committee, q5478.

84 Ibid., q109.

85 Martell, 23.

86 Ibid, 2. 
Third and fourth, the risks associated with sea cocks and pumps he thought had been reduced in recent years as a result of growing awareness and therefore improved arrangements. About machinery failures, his fifth cause, he noted:

The greater experience acquired in the management of steamers has forced upon owners and managers the necessity of a special and careful examination of the engines on the return of the vessel from every foreign voyage, and the employment of superintendent engineers, in order to avoid the risk of a break down, and the attendant consequences which may follow, not only in the loss of the vessel, but of delay and cost in putting into a foreign port for repairs. Too much importance cannot be attached to it. $^{87}$

He said it was not his place to remark on navigation, cause six, and likewise he believed his views on the tenth cause of loss, overloading, required no further comment.

Behind the problem of inadequate protection for deck openings, his seventh cause, lay the issue of measuring tonnage. Proper protection as afforded by high iron coamings was needed so as to reduce the chance of heavy seas forcing them in, or large bodies of water resting on them. "This was discouraged by the space so enclosed being added to the tonnage measurement, and so adding to the working expenses of the ship. The same may be said of the protection round the openings of the engine and boiler space." 88

Hasty and improper loading was definitely a problem for two reasons. First, loading grain in bulk could be a concern. Were the shifting boards adequate? (New York gave specifications.) The second problem was the basic ignorance of many captains and officers of how to load any cargo. This point was made during the discussion of Martell's paper. ${ }^{89}$ Worse, it was condoned by no less a person than the commissioner of wrecks who conducted inquiries into lost ships. In his report on the loss of the Heimdall, he accepted ignorance as a valid reason.

Now undoubtedly, if anyone is to blame, it must be the captain; at the same time we are not to expect any extraordinary amount of knowledge and discernment from a person in his position. It seems that this was the first grain cargo in bulk that he had ever carried, and if he showed a reasonable amount of care and attention to the stowing of this cargo we can hardly punish him, even if the means which he adopted should afterwards prove to be insufficient. ... if the means which he took for the purpose proved not to be sufficient it was owing rather to want of knowledge than to want of care. ${ }^{90}$

\footnotetext{
87 Ibid., 5.

88 Ibid., 16-7.

89 Ibid., 46.

90 Select Committee, App 11, 369a.
} 
How a vessel was loaded was also an important consideration in the stability of a vessel. Merchant officers were not then examined for their certificates in how to load a vessel. Henderson answered a question from Reed with his own question: "How many men are there going to sea who know the science of stowage?"91 Obviously he did not think many. Farrer would recommend language for legislation that was clearly meant at least partially to close this loophole.

Martell's ninth cause of loss related to design. During the discussion of his paper it became apparent that some builders' yards did not even make, let alone provide to the owner, stability calculations. This was one of the findings of the court of inquiry into the loss of the Marlborough, built in 1878. "From the first to the last no one ever seems to have calculated the stability of the vessel, the position of her centre of gravity, or with the amount of cargo and to what depth she could be safely loaded; all these were questions with which both the builders and the owner seemed to think that it was quite unnecessary to trouble themselves." ${ }^{\prime 2}$ At the Kensington inquiry the designer said, "I have never made any calculations as to her stability;" the owner's superintending engineer said "I never considered her stability" and the builder's manager said "We never calculate the stability of vessels we build; we never calculate the position of the metacentre."93 Similar statements are made in several other inquiry reports submitted by Farrer on 10 June. This serious indictment of shipbuilding could not be solved by stowing grain differently.

The difference between Martell's careful analysis of the reasons of loss and Plimsoll's simplistic approach was profound. In his February bill Plimsoll had forwarded his solution to the problem he had defined as putting the grain in bags, sacks or barrels. There were two important questions related to grain in bags: did they affect cost, and did they alter the centre of gravity in a ship? Plimsoll was adamant that bags would not increase the cost of shipping grain versus grain in bulk despite all evidence. Martell, whose paper Plimsoll had commended, was unequivocal. "That it would be more expensive there cannot be a doubt, and my enquiries have led me to the conclusion that this would amount in an American voyage to about $8 \mathrm{~d}$ per quarter, or say $£ 360$ per voyage in a vessel of about 1,200 tons net register, including the cost due to delay in loading." 94 When Wilson challenged Plimsoll that bags could increase costs for a [large] firm by as much as $£ 35,000$ a year, Plimsoll replied "No, I would not believe it even if you told me it was your own firm." ${ }^{95}$ Rather, Plimsoll believed and reported hearsay evidence:

\footnotetext{
91 Ibid., q1656.

92 Select Committee, q1656; Martell 38, 43, 47,49, 50; Select Committee. Appendix 11, 402a.

93 Select Committee, Appendix 11, 409a.

94 Martell, 22-3. Today's reader might not be familiar with the old English currency. The largest unit was the pound (£). It was divided into twenty shillings (s), each of which had twelve pence or pennies (d). Coinage included a halfpenny and a quarter of a penny, called a farthing.

95 Select Committee, q340.
} 
I have just one more word to say as to the people who say it will be so much more expensive to adopt this remedy. There is a list of 17 firms and companies that are willing to supply sacks at a cheap rate, either hire or sale. The rate for a three-bushel sack is sixpence, and they give twopence back at the end of the year, so that you have the use of a three-bushel sack for fourpence; and a ship will make eight trips to New York and back, so that you provide sacks at the cost of a halfpenny for three bushels per voyage. ${ }^{96}$

Those confident statements on the useful life of a sack and cost were contradicted by other witnesses, including at least one Plimsoll supporter.

William Dickinson had been recommended as a witness by Plimsoll. ${ }^{97}$ By comparison with some of the other witnesses, he was a small shipowner of limited experience. After twenty years in sail, he had owned five steamships for only ten years. ${ }^{98}$ Reading the evidence today, overall he did not seem a credible witness. For example he disputed official figures on the number of ships lost (none) carrying grain from the Baltic. ${ }^{99}$ On the question of the cost of putting grain into bags, he first said he did not know, then he refused to believe it could be $6 \frac{1}{2} \mathrm{~d}$ per quarter, all after having said when asked by earlier by a different committee member if the cost might be $3 \mathrm{~d}$ per quarter, "Oh dear no; a farthing or a halfpenny. I am sure it could not be more than a halfpenny, and perhaps you will excuse my answering the question." ${ }^{100} \mathrm{He}$ agreed with Plimsoll that a bag cost sixpence ${ }^{101}$ but not on how long a bag's useful life was. He suggested that a year had only five voyages, thus impacting Plimsoll's cost calculation. He further believed that the insurance on a cargo in bags was cheaper than insurance of a bulk cargo, thus mitigating costs. He said that the insurance rate on grain shipped in bulk was 30s per cent but in bags only 15 s per cent. ${ }^{102}$

While a lower insurance rate for grain in bags may indeed have been Dickinson's experience, it says much more about his inability as a shipowner and reliability as a witness. He was convincingly refuted on that point by Frederick Leyland, the managing owner of twenty-five steamers sailing in the Black Sea, the Mediterranean and the Atlantic. Additionally, he was a member of the Liverpool Steamship Owners Association and was specifically authorized to speak on their behalf. That association collectively owned approximately one-third of the British steamship tonnage. Eleven lines ran ships between Liverpool and the United States, including Cunard and the National Line; they carried "nearly 50 per cent" of all

\footnotetext{
96 Ibid., q118 (p11 col b).

97 Ibid., q9211.

98 Ibid., qq301; 697-99.

99 Ibid., qq1162-5.

100 Ibid., qq1169, 1171, 1059.

101 Ibid., q1447.

102 Ibid., q742.
} 
the grain imported through Liverpool. ${ }^{103}$ Leyland had heard Dickinson's evidence and was "rather astonished" by his insurance comments. "I have got here a host of policies of insurance for vessels coming from the Atlantic seaboard, from different ports, in the winter months, and the rate of insurance by none of them, although the grain is to be loaded in bulk, is more than 10s., and a great number of them are 6s.8d. per cent." 104 Obviously if Dickinson was "frequently" paying 15 s per cent for grain in bags in the winter, as he said, ${ }^{105}$ he was paying at least half as much again as Leyland's highest rate in bulk, and also paying for his bags. The point was not lost on MacIver.

Dickinson's evidence on other important points was also dismissed. One of the most important questions was whether bags affected stability. ${ }^{106}$ The volume of cargo that could be carried was a related question. Stability and loading (or overloading) were integral to Plimsoll's overarching objective of improving safety at sea. Plimsoll assumed that as a cargo in bulk if not properly stowed could shift, therefore a cargo in bags that was less likely to shift would be safer. Dickinson did not understand the problems of space and weight. Asked on that specific point by Chamberlain, Dickinson said that by measurement, bags for a cargo of 10,000 quarters had a deadweight of twenty tons and occupied thirty-two cubic tons. He also said that for the same quantity of grain, bags (despite adding weight) would lower the centre of gravity. ${ }^{107}$ From that there seem to be two inescapable conclusions: either less cargo (and therefore less earning capacity) was carried or the ship was more heavily laden.

But Dickinson believed more cargo could be carried in bags than in bulk. ${ }^{108}$ He said he loaded an additional 420 quarters because, "you see you can put the bags on the ship's floor from stem to stern, and then you can put the second tier on the other way and go on crossing tiers as you go up, and then when you come to the 'tween deck of the ship you can stow the bag chock home, and the ship with

\footnotetext{
103 Ibid., qq4560-7, 4583.

104 Ibid., q4654.

105 Ibid., q744.

106 "A ship's ability to float depends upon two factors, her weight and her buoyancy." These determine the centres of gravity (the pressure of the total ship's weight pressing down) and buoyancy (the total pressure of the water forcing the ship to float). The centre of gravity for any voyage will essentially be fixed, altered only by fuel, water and stores consumption, but the centre of buoyancy moves as the ship rolls in the swells and waves. The lateral distance between the centre of gravity and the centre of buoyancy at any moment is called the righting lever. The effectiveness of that is a function of the metacentric height. That is the variable distance between the point where a vertical line from the centre of buoyancy at the moment of a roll intersects a vertical line drawn from the centre of gravity when the ship is in an upright condition but at any given moment will be on an angle according to the roll of the ship. The shorter the metacentric height, the less able the ship is to right itself. Raising the centre of gravity reduces the metacentric height and therefore the stability of the ship. Admiralty Manual of Seamanship (London: HMSO, 1952) 2: 495 -9.

107 Select Committee, qq774-8.

108 Ibid., qq1029, 1033.
} 
a cargo of bags is literally as full as an egg." 109 He obviously did not understand that loading in the forepeak would reduce seaworthiness, ${ }^{110}$ but his contemporaries did. Henderson said "the more you bring the cargo from the two ends of the vessel, you make the vessel more seaworthy." In answer to another committee member he said, "if you extend the cargo into the ends of the vessel she becomes awkward and unsteady" and "if you carry cargo at the ends of the ship it makes her outrageously unsteady" and finally, "the more you contract the cargo to the centre the better." "John Brough Palmer, "engaged in the management of the great works at Jarrow," agreed. "If you bag the grain so as to increase the volume of the grain so much that the ends would be filled, then you interfere most materially with the stability of the ship." "112 This ought not to have been new to anyone but rather well and widely understood. At the 1867 meeting of the INA Nathaniel Barnaby who under Edward Reed did much of the work on stability, gave a paper on loading merchant ships. He said, "a dangerous practice is sometimes tolerated of bringing a ship to trim at the last moment by stowing heavy goods at the ends of her. This is fatal policy, and has been the ruin of many a good ship." 113 That Dickinson did not know this more than a decade later points to a serious lack in his professional knowledge. Palmer continued, "I do not see how Mr Dickinson could have got more grain into the lower hold of a ship by filling the grain into bags." 114 Nathaniel Dunlop was a partner in the Allan line. He also spoke on behalf of the Henderson Brothers' Anchor Line, and the Glasgow based State Line and Donaldson Line. ${ }^{15}$ He was later Sir Nathaniel and Allan Line chairman. He agreed that grain in bags would raise the centre of gravity "to a dangerous extent." 116 The 1873 assessment of Somerset's commission on the lack of utility of witnesses recommended by Plimsoll might equally have applied to Dickinson.

Captain Henderson followed had Dickinson as a witness and heard his testimony about the quantity of cargo. He called it "hocus pocus." He suggested that bags occupy 6 percent of the available space. That would appear to have been a very generous estimate. Leyland put the figure much higher. Early in his testimony he said "there is no doubt that one of the principal advantages of grain in bulk is that it serves as ballast. Grain in bags would certainly take up from 15 to 18 per cent more room than it would if shipped in bulk." After hearing Dickinson's comment to the contrary, he had caused his previous calculations to be checked by others, including the Cunard line, the National Line, and several others. "They all bore out

\footnotetext{
109 Ibid., q773.

110 Ibid., qq1509, 1564, 1561. "As cargo weight is moved forward into the forepeak, buoyancy and manoeuverability are adversely affected." (Admiralty Manual of Seamanship (London: HMSO, 1964), 3: 21).

111 Select Committee, qq1561, 1960,1962, 1963.

112 Ibid., qq3158, 3338.

113 Nathaniel Barnaby, "On the Stowage of Merchant Ships," Transactions of the Institution of Naval Architects 8 (London: Institution of Naval Architects, 1867), 13.

114 Select Committee, qq3158, 3338, 3340.

115 Ibid., q4745.

116 Ibid., q5021.
} 
the correctness of my measurements ... it is clear that for all purposes of ballast grain in bags would be proportionateley higher in the ship, and consequently of less effect in giving stability." 117 Derek Pickney, a Sunderland ship owner with ten ships, master of several years, chairman of the Sunderland Shipowners' Society and authorized to speak on their behalf, said, "I was present here and heard the evidence of Mr. Dickinson, and he is the only person I know who holds the view [of grain in bags] so strongly. I do not know another." 118

Glover's testimony spanned three days (only Farrer's was longer), and included a combative exchange with Sir William Harcourt. In one instance this led Glover to submit a letter supporting his evidence. ${ }^{119}$ From his opening answers, it was clear that his comments were fact based which, given his study of shipping statistics, cannot be surprising. On the utility of bags, he said, "I think with regard to some heavy grains, partial bagging might increase safety; with regard to putting entire cargoes in bags, I think it would lead to a great many casualties which we now escape ... because our greatest source of danger at present is tenderness and over-loading." The problem was stability. ${ }^{120}$

On the matter of cost of bags, he began by pointing out that requiring bags was "something quite novel, to compel the carrier of goods to provide packages. ... [it would] introduce into carriage a totally novel doctrine." ${ }^{121}$ He then went on to describe how the grain trade worked. If bags were used, they were provided by the owner of the grain. The grain was delivered at the end of the voyage as it had been received, either in bags or in bulk. Therefore there was no advantage or cost saving to the unloading or the onward transportation of bagging bulk grain as Plimsoll had suggested. ${ }^{122}$ If grain had to be put into bags, they were bought at the point of loading. "I do not think the cost of bags in Dundee or in London has anything to do with this question. ... The question is, what can we get bags at in America; when we not only want them, but when we must get them in a few hours." He continued,

You asked me just now why we do not buy bags in this country. It happens sometimes that we send vessels to the other side of the Atlantic not knowing what they will bring back. We send them to the Atlantic coast for our orders. We make arrangements while they are crossing the Atlantic and cable them where to go to; we may engage them to load grain, in which case we want some bags, or we engage them to load provisions, or cotton, in which case we do not want bags, and any vessel that loads grain one voyage may load cotton the next, or may go to India the third voyage, and load a cargo of grain, in which case the shipper provides the bags; so that the necessity for bags on board our vessels is not a constantly recurring

\footnotetext{
117 Ibid., q4571.

118 Ibid., qq3448 -54, 3513.

119 Ibid., App 19, 439.

120 Ibid., qq2241-4.

121 Ibid., q2391.

122 Ibid., q464.
} 
necessity which makes it in our interest to keep them. Then they are very rapidly destroyed on board the ships; they are subject to very rapid waste and destruction if they are kept unused. ${ }^{123}$

This is a very neat description of the working life of a tramp steamer. As many British cargo ships were neither in a liner service providing scheduled runs between ports, nor built for a specialized cargo such as oil, the evidence of how the trade worked was very important. Similarly Leyland said his steamers were never employed exclusively in the grain trade. ${ }^{124}$ The assumption that a ship would routinely make consecutive voyages carrying grain thus reusing bags, was clearly suspect.

Glover also provided needed factual testimony on all the related costs of putting a portion of a grain cargo in bags. In a written submission he itemized the expenses of five cargoes. These included the hire of bags, cartage, elevating charges, opening and emptying bags, bundling up and tallying as well as other expenses. Amortized over the entire cargo, the cost per quarter of grain varied from one penny to fourpence halfpenny. Citing the example of a cargo loaded at Montreal, the required bagging cost $£ 14318 \mathrm{~s} 6 \mathrm{~d}$; had the entire cargo been in bags, the cost would have been $£ 57716 \mathrm{~s} 7 \mathrm{~d} .{ }^{125}$ That fourfold increase of cost would have added tenpence to each quarter, or more than a penny per bushel. Although not remarked on in testimony, requiring all grain cargoes in bags could have had a cumulative effect on the price of food.

Walter Cummins, a grain sampler and general agent, spoke to another element of the grain trade which was an obstacle for bags. "When the grain cargoes come in, merchants write to my house asking to have an examination of the cargo made, and we send off a sampler with a piercer, which is a long-handled spear. This piercer is put down into different parts of the cargoes, and samples drawn from the different parts."A report would then be written and sent to the merchant. He added, "I may be allowed to mention that if cargoes are entirely shipped in bags, it must change the whole regulation of the trade, because of course it is apparent that you cannot get a piercer through the bags." 126

The proposed requirement that all grain cargoes be carried in bags, sacks or barrels was intended as a solution to a perceived problem of excessive loss of grain ships at sea. Regardless of how well Plimsoll and his adherents did or did not understand the fundamentals of stability, there were other problems. First, was the underlying assumption of preventable loss at sea in fact correct? Second, what was the cause of loss?

Plimsoll had provided the committee with figures suggesting a large number of grain vessels were lost between the winters of 1873-4 and the winter season recently ended. He went on to say, "of those losses, I believe, the large proportion

\footnotetext{
123 Ibid., q2408.

124 Ibid., q4692.

125 Ibid., Appendix 17, 437, qq2396-9.

126 Ibid., qq5086, 5125.
} 
is owing to the bulk loading ... bulk loading is in itself sometimes fatal." ${ }^{127}$ Both his facts and his assessment were challenged by Farrer's documents and Martell's paper. They both explicitly pointed out that as ships other than grain ships were being lost, the cause could not be just grain cargoes. That grain cargoes were not particularly dangerous was also demonstrated by others. G.A. Laws, an owner speaking on behalf of the Liverpool Underwriters Registry, the North of England Steam Shipowners Association and the North Shields Shipowners Association, thought legislation was not necessary because "the per centage of loss is so small through the loading of grain in any way." He subsequently said, "we have only four instances in the last eight years of vessels being lost through the shifting of cargo or that are known to have been lost through the shifting of cargo." Dunlop likewise said that grain in bulk was not the cause of loss for grain laden ships. ${ }^{128}$

Martell was the penultimate witness, appearing before Farrer's third visit. His first challenge was to try to educate Chamberlain and others about "Lloyd's." They did not understand that the Register of Shipping and the Insurance were separate and distinct although they were both named Lloyd's. (That there was a problem at least with Chamberlain, the cabinet minister responsible for shipping, is an interesting reflection on his understanding of the business. It may help explain why he was so easily led by Plimsoll.) Several MPs wanted Lloyd's Register to act definitively thus "solving problems" where Parliament did not want to act, such as on the load line question. They uniformly appeared to fail to understand that Lloyd's Register, a voluntary, non-incorporated society of members, lacked Parliament's authority to impose through legislative action. ${ }^{129}$

With respect to the question before them, Martell reinforced the conclusion of his INA paper. Early in his testimony he said, "I believe the primary and greatest cause [of the loss of ships] was the want of stability, but the shifting of cargo contributed of course, to the danger; and anything that can be shown to lessen that tendency to shifting would lessen the danger to some extent." ${ }^{130}$ Behind this statement, obviously endorsed by Reed, lay the weight of his careful research. It was in clear contrast with Plimsoll's quasi-religious belief in the danger of shifting grain cargoes. He noted that over the recent winter that equal numbers of ships carrying homogenous cargoes of grain and of coal were lost suggesting the problem was not shifting but stability. He again pointed a finger at shipbuilding. "Unfortunately shipbuilders do not go sufficiently into the question of stability as they should do, I am sorry to say. It is a question now giving rise to more interest and the thing is being gone more into, but hitherto I do not think it is a question which shipbuilders, even our greatest have gone into to such an extent as they

\footnotetext{
127 Ibid., qq114, 115.

${ }^{128}$ Ibid., qq4085-7, 4088, 4106; 477, 4772.

129 Ibid., q5227.

${ }^{130}$ Ibid., q5254.
} 
might have done."131 (In 1874 Palmer's own yard had built the Tiara. The ship's designer "had not calculated the position of its centre of gravity, and that it would take him a fortnight or three weeks to work it out." ${ }^{132}$ ) In response to a question from Reed, he agreed "the judicious use of shifting boards and the stowage of part of the grain in bags would contribute to diminish the loss." 133

Farrer's final appearance before the committee was to give his opinion evidence. As with every other witness, Chamberlain opened the questioning. This time it was of his senior official. It began with a discussion on the international aspect of shipping. In part this may have been for Harcourt's benefit. In 1876 he had moved an amendment to have a clause apply to all shipping because Britishonly restrictions "would tend very much to drive British ships out of the trade."134 Mining or railways, both Harcourt's responsibility as the home secretary, could be regulated without international impact. Shipping was different and the bill before the committee allowed that any foreign ship delivering grain to Britain that was not in accordance with the British law could be fined double the harbour dues. ${ }^{135}$ Farrer carefully elucidated why British shipping regulations could not apply to foreign shipping in British ports. Any attempt would almost certainly lead to very injurious retaliation against British interests. ${ }^{136}$ On the other hand, imposing restrictions only on British ships of how much cargo or how it could be carried would erode the national advantage in an international trade. This was certainly a factor in the British shipowners' opposition to the Plimsoll agitations. If this liability was understood, some, including Plimsoll, did not seem to think it a factor worthy of consideration. Even so, it was the reality within which policy makers and Parliament had to operate.

They then proceeded to review the evolution of inquiries into the loss of ships, since they began in 1851. Farrer believed that wherever possible the onus of responsibility should be with the shipowner. When invited to suggest how legislation might be further improved, his first comment was to ensure that in any legal proceeding "the burden of proof should be thrown on the shipowner, and that he should be bound to show, not that the grain had shifted, but that he had taken all reasonable precautions to prevent it from shifting." 137 That would doubtless have changed the finding in the Heimdall inquiry. If a penalty from a successful prosecution could be recovered from the owner as well as the master, Farrer thought "it would put on the shipowner the duty of finding out what was the best way of preventing his cargo from shifting." 138

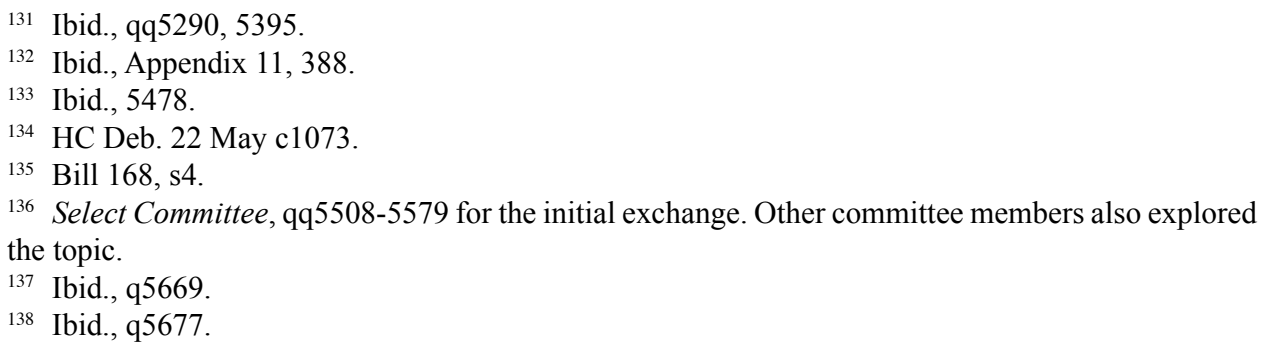


Inquiries led easily to a review of what the Board of Trade had been doing about the current agitation. Farrer reported that in April 1879 his staff had become concerned about the loss of steamers of a common type. Work was well underway before Plimsoll's December decision. As a result of investigations Gray, the head of the Marine Department, wrote a memo on 1 January 1880 outlining their findings. Sandon, then the president of the Board of Trade, responded on 14 January that "in the case of all ships reported to the Board of Trade as foundered or missing, an inquiry hereafter should be ordered. It will also be desirable that statements should be drawn up in the office showing the main features of each similar case." ${ }^{139}$ Farrer remarked, "if it had not been for that agitation, and for the way in which the time of the Board of Trade has been taken up, we should probably have made more progress than we have with those cases." 140 Under questioning from Talbot, Farrer returned to the theme that "attention has been diverted from what has been the real evil by this agitation about bags." The real evil he defined not as grain laden ships but "the class of high deep three-decked vessels, frequently with water ballast, which carry homogenous cargoes, and many of which have foundered from want of stability." 141

Farrer's evidence was concluded on Monday 19 July. That Thursday the committee met to consider a draft report, which recommended that the Anderson bill not be proceeded with. Given the pro-Plimsoll bias of both the Anderson bill and Chamberlain and Harcourt, this was a significant recommendation. First, grain in bulk was not the problem; it was stability and legislating grain would not solve it. Then the case against the bill presented by recognized leaders in the shipping community was overpowering. The expense of bags, the potential damage to the British grain trade and the lack of need to legislate, were each sufficient grounds not to proceed. But given the political realities, something had to be done. What?

The draft report provided elements that should be included in any new legislation. The third paragraph gave a clear statement of intent. The committee was "of the opinion that, with a view to greater security of life, it is desirable that the measures which have been found to be necessary for this end, and which are already adopted voluntarily by the majority of shipowners, should be made compulsory on all by legislative enactment." 142

Farrer's concerns about the effectiveness of inquiries were acted upon. The only contentious moment was the vote over a clause to place the onus of proof on the shipowner for having taken all proper precautions to prevent a cargo shifting. Chamberlain had to break a tie vote, the four shipowners present all voting against. ${ }^{143}$ A suggestion from Wilson to facilitate inquiries, with which Farrer agreed, was to require a master to leave a loading plan with the British consul at

\footnotetext{
139 Ibid., q5723.

140 Ibid., q5722.

141 Ibid., q6090.

142 Ibid., $\mathrm{x}$.

143 Ibid., xi.
} 
the departure port. ${ }^{144}$ As amended, the report was agreed unanimously. Therefore when the report went to the House, there was no basis for further debate. The report's recommendations were converted into a bill that Chamberlain presented to the House, seconded by his parliamentary secretary, the younger son of Plimsoll's great patron, Lord Shaftesbury. This meant government support and checked any potential for complaint from Plimsoll or his supporters. It was slightly amended in committee and reprinted. On 25 August the House of Commons gave it third reading. It passed quickly through the House of Lords and received royal assent on 7 September. ${ }^{145}$

As adopted the bill applied to grain laden ships crossing the Atlantic or the Bay of Biscay, which meant cargoes coming from the Black Sea or the Mediterranean. The definition of grain laden was rephrased from the 1876 legislation but remained as more than one-third of the cargo in grain. All such ships had to have at least onequarter of the grain in bags. The analysis both by Martell and the Board of Trade on the recent losses at sea ably demonstrated that the cause of the losses was not shifting grain cargoes.

Again we can ask, what had Plimsoll achieved? Were the 1880 measures a significant advance on the 1876 legislation? Was it something Plimsoll would have wanted? The new law gave legislative force to what was being done as a result of the Montreal and New York regulations. The requirement of at least one-quarter of the grain in bags had been suggested by both Gourley and Plimsoll in 1876. In 1880 a number of witnesses had spoken in favour of the Montreal regulations. Glover pointed out that the amount of grain required to be in bags at Montreal varied between 24 percent and 30 percent, but never as much as one-third. He believed that for ships carrying heavy grains across the Atlantic, one-fourth should be in bags. ${ }^{146}$ Obviously this was not the complete ban on bulk cargoes that Plimsoll had wanted. The new law did not have any of the prescriptive measures Plimsoll had advocated. The emphasis on the responsibility of the owner was clarified and the ability of the government to prosecute was simplified. While Plimsoll could and probably would have accepted the grain cargoes bill, he would still have wanted more.

What was Plimsoll's part in the grain cargoes legislation? Certainly he initiated the agitation that led to it. But as Farrer pointed out, it diverted attention from the real problem, the loss of ships because of stability problems that Plimsoll did not understand. The papers Farrer submitted along with Martell's evidence, and of course the discussion around his INA paper conclusively demonstrated that the problem was not grain cargoes. The inquiry of a select committee was able to elicit information that the 1876 Committee of the Whole debate along partisan lines could not. Plimsoll's conjecture and hearsay evidence and that of his supporters were solidly refuted by the hard fact of other witnesses. The need for action was not

\footnotetext{
144 Ibid., q6180.

145 Bills 287 \& 315, Merchant Shipping (Carriage of Grain) Act, 1880,43 \& 44 Vict.

146 Select Committee , qq2828,3026-8.
} 
substantiated, but the potential damage to British trade was. The recommendations of the report were clearly in line with the thoughts of the Board of Trade and importantly, supported by British shipping.

The bill did not "put and end to the loading of grain in bulk" that on 2 January the Times had announced Plimsoll was seeking. The face saving "out" for Chamberlain and Harcourt was to bring forward "something" that was acceptable to the shipowning community, demonstrate action to placate public opinion and claim a victory. Looking back from 1892 when Glover was giving his fourth decennial paper on tonnage statistics he identified the Carriage of Grain Act as one of the three most important pieces of shipping legislation of the fifteen adopted in the period. Another was the Load Line Act of $1890 .{ }^{147}$ Both completed work connected with Plimsoll's agitations.

Plimsoll did not accept stability as the real problem. As the legislation his agitation prompted could not address the important cause of loss, it is hard to hail it as a success notwithstanding its imposition of minimum safety standards on wayward shipowners. All the evidence conclusively showed the losses had been caused primarily by problems of stability, not shifting cargo. Where the Somerset commission had recognized Plimsoll's role in drawing attention to load lines, in 1880 work was already underway on analysing the stability problem, a necessary preliminary to addressing it before the agitation. Following Martell's 1880 paper supported by the damning evidence from the courts of inquiry collected and published in the Select Committee report, individual INA members clearly thought about the real problem and how it was best resolved. At the April INA meeting William Denny, a Dumbarton shipbuilder, in his paper about the education of naval architects suggested the examinations set for draughtsmen working in shipyard design offices needed updating. That meant revising the curriculum. He pointed out that one of the obvious gaps in the current curriculum was "the stability of vessels, treated even in the simplest form, with reference to the metacentric height, and its alterations by the combined influences of change of draught and vertical change of weight." Ultimately the responsible agency was the Board of Trade, for it had established the Department of Science and Art to provide training and education in industrial design. In early July Lord Ravensworth the INA president, led a delegation to government to press for that recommended change. By early December a new syllabus for naval architecture introducing stability calculations at the second stage and pursuing them in the honours stage had been adopted. This time the solution did not need legislation.

147 John Glover, "Tonnage Statistics of the Decade 1880-90," Journal of the Statistical Society 45 (1892), 207.The third was the Payment of Wages Act, 1880. 